\title{
ENHANCING RISK-RELATED DISCLOSURE IN SOUTH AFRICA: A STUDY ON GUIDELINES AND CURRENT PRACTICES
}

\author{
Zack Enslin* \\ Stellenbosch University \\ zack.enslin@up.ac.za
}

\author{
Wilna Bruwer" \\ Stellenbosch University \\ bwsl@sun.ac.za
}

Received: November 2013

\author{
Christa Viljoen+ \\ Stellenbosch University \\ cviljoen@sun.ac.za
}

Accepted: May 2014

\begin{abstract}
Investors partake in the risk of a company, in expectation of a return on investment which is in accordance with the company's risk profile. Due to recent corporate failures, which are partly attributable to insufficient risk management, a call by investors for enhanced risk-related disclosure resulted in the publication of various international standards and guidelines on best practices for risk disclosure. This study compiled a disclosure index from these standards and guidelines in order to serve as a disclosure-enhancing tool for the management of South African companies. This index was subsequently used to investigate current practices exhibited by top listed companies in South Africa. Disclosure practices by these companies indicate that there is scope for improvement in riskand risk-management-related disclosure by these companies.
\end{abstract}

Keywords

Risk disclosure, risk management, risk identification, disclosure index, current practices

* Mr $\mathbf{Z}$ Enslin is a lecturer at the School of Accountancy, University of Stellenbosch, South Africa.

\#Prof BW Bruwer is a professor at the School of Accountancy, University of Stellenbosch, South Africa.

+Ms C Viljoen is a lecturer at the School of Accountancy, University of Stellenbosch, South Africa. 


\section{INTRODUCTION}

An increase in the complexity of the business environment, rapid changes in technology and the globalisation of markets increased risk from the investor's point of view. The larger risk exposure led to a sentiment among investors that they are entitled to more information on the risks that the company is facing that management have access to (Rajab \& Handley-Schachler, 2009). Recent corporate failures ignited the demand amongst investors for improved risk and riskmanagement disclosure, due to a generally accepted view that risk was underestimated before the 2007 financial crisis (ICAEW, 2011:2). However, according to Miihkinen (2012) previous research on risk disclosure indicates a deficiency in risk information.

Abraham and Cox (2007:227) are of the opinion that risk reporting forms part of the foundation of financial management and investment practice, as investors use the information on risk in determining the risk profile of the company, and thereby inferring the return that they expect. The expected return, in its turn, forms part of the cost of capital of the company, which can be lowered by management disclosing the correct information on risk and risk management to the investors. For management, the advantage of improved risk reporting lies in the potential for a more stable environment for investment activity and capital accumulation (Rajab \& HandleySchachler, 2009).

According to the Institute of Chartered Accountants in England and Wales (ICAEW, 2011:2) enhanced risk disclosure in public documents should inspire management to improve risk management.

In the aftermath of the global financial crisis, various international bodies conducted their own research into the requirements of investors and the possible improvement of risk disclosure. This current study utilises this knowledge extracted from practice by the international bodies in order to develop a risk-disclosure index. This index therefore reflects the preferences of international investors with regard to risk disclosure. The management of any publicly traded company can use the risk-disclosure index as a tool in order to improve its risk and riskmanagement disclosure. The risk-disclosure index is then used in this study to infer a current benchmark of practices in the reporting of risk by Top 40 companies listed on the JSE Securities Exchange (JSE), excluding companies listed in the financial sector.

The board of directors of a company forms the ultimate managerial level of a company and is accordingly frequently referred to in the literature and discussions that follow.

\section{CURRENT RISK DISCLOSURE RELATED LITERATURE}

\subsection{International studies on risk and risk management disclosure}

Although improved risk and risk-management disclosure is becoming increasingly important, international studies found large variations and deficits in risk disclosure (Lajili \& Zéghal, 2005), even in the presence of disclosure rules and incentives (Dobler, 2008:200). Oliveira, Rodrigues and Craig (2011:818) report that previous studies found disclosure of risk and risk management to be 'vague, generic, qualitative, backward looking and inadequate for the information needs of stakeholders'. Merkl-Davies and Brennan (2007:181) suggest in their study that discretionary narrative disclosure runs the risk of becoming impression management, instead of providing valuable incremental disclosure. Abrahamson and Amir (1996:1159) found 
that narrative disclosure can however assist investors in better prediction of the performance of the company.

Other international research on risk and risk-management disclosure addressed different areas. Studies have been performed on relationships of risk-disclosure practices to other company indicators, such as size and financial performance (Linsley \& Shrives, 2006; Linsley \& Shrives, 2005), market-value indicators (Jorgensen \& Kirschenheiter, 2003), and composition of board of directors (Abraham \& Cox, 2007), including a combination of these indicators (Amran, Bin \& Hassan, 2008), in order to find what drives disclosure. Other earlier international studies also measured the quality of risk disclosure to a self-developed framework or index (Holt, 2006; Beretta \& Bozzolan, 2004).

\subsection{South African studies on risk and risk management disclosure}

Most previous South African studies focused on corporate governance disclosure (Ntim, Opong, Danbolt \& Thomas, 2012; Barac \& Moloi, 2010; Abdo \& Fisher, 2007; Janse van Vuuren, 2006; Vorster \& Lubbe, 2000) or integrated reporting disclosure (Deloitte, 2012). As such they examined risk disclosure as one small part of either corporate governance disclosure or the integrated report, and did not report on risk disclosure in much detail.

In a study performed after the King Report on Governance for South Africa 2002 (I0D, 2002), referred to as King II, was issued, Abdo and Fisher (2007) surveyed companies listed on the JSE and scored disclosure in 2003 and 2005 for various aspects of corporate governance, of which risk management was one. According to this study risk management scored $57 \%$ in 2003 and improved to $62 \%$ in 2005 . They also reported that of all the sectors, banks with a score of $80 \%$ and life insurance with a score of $77 \%$ ranked the highest on risk-management disclosure. According to them the reasons for this phenomenon were the South African Reserve Bank regulations as well as the Basel II Report, which specifically refers to risk-management disclosure.

The improvement in mandatory risk disclosure was also found in voluntary risk-managementrelated disclosure. Ntim, et al. (2012:133) found that voluntary compliance varied substantially; however, with reference to five areas of voluntary risk-management-related disclosure, the study found that disclosure generally improved from 2002 to 2006.

Barac and Moloi (2010) studied the 2006 annual reports of the non-financial Top 40 JSE listed companies in order to assess the corporate governance reporting as required by inter alia the King II report. They reported that $87.5 \%$ and $72.5 \%$ of assessed companies complied with required information in the areas risk management, and risk management and internal audit respectively. The King II report required that important risk-management information be disclosed either in the company's annual report or to the shareholders at the annual general meeting (IOD, 2002).

Havenga and Venter (2007) investigated the perceived value of enterprise risk management from the point of view of the board of a company, using disclosure in the annual reports as a starting point. The study found that compliance was a key driver and not the possibility that risk management could be a strategic tool for management to achieve a competitive advantage.

Coetzee and Lubbe (2013) developed an adapted risk-maturity model in order to investigate and compare the risk-management maturity levels of a selection of private and public sector 
companies. They found that, on average, private companies were risk-mature, unlike public sector companies, which lacked maturity.

Although Coetzee and Lubbe (2013) discovered risk-management maturity in private sector companies, another recent South African study on integrated reporting performed by accounting and related services firm, Deloitte, confirmed the prevalence of superficial risk disclosure by private sector companies listed on the JSE (Deloitte, 2012). The report (Deloitte, 2012:28) concurs that although a significant proportion of the companies with year-ends during the latter half of 2011 disclosed the risks facing the company and provided a risk-mitigation plan, the risks disclosed often lack depth and typically dealt with generic risks facing corporate South Africa.

There is therefore clearly a need for an improvement in risk disclosure, also in South Africa.

\subsection{Guidelines and requirements on risk and risk management disclosure}

The most important current guidelines and requirements will briefly be referred to below. These include non-binding guidelines that aim to assist the management in preparing optimal disclosure. This seems appropriate, as Dobler (2008:200) as well as Berk and Loncarski (2011:134) found that regulation does not serve as a sufficient incentive to enhance risk and risk-management disclosure.

The International Accounting Standards Board (IASB, 2010) issued a practice statement regarding management commentary that relates to financial statements that were prepared in accordance with International Financial Reporting Standards (IFRS). This statement serves as a non-binding framework to assist the board and management in preparing management commentary. Paragraph 32 of the statement discusses risk-management process-related disclosure, and paragraph 33 discusses disclosure of the physical risks and uncertainties.

A team drawn from the major risk organisations in the United Kingdom (UK), in consultation with other professional bodies with interests in risk management, developed the Risk Management Standard (IRM, 2002). The purpose of this standard is to provide best practice against which entities can measure themselves. The standard (IRM, 2002) addresses risk-management process-related disclosure, such as controls in place, responsibilities and monitoring and review of these systems.

Also in the UK, the Financial Reporting Council (FRC, 2011) held a series of meetings with directors and heads of risk and internal audit of 40 major listed companies, as well as with a selection of investors and advisors, inter alia about the disclosure of risk management. This resulted in a document that attempts to capture contributions in order to be helpful to other companies. This document focuses on whether risk disclosure is linked to the company's strategy and business model.

The Institute of Chartered Accountants of England and Wales published a report 'Reporting business risks: meeting expectations' (ICAEW, 2011) as part of its 'Information for better markets initiative'. This report suggests certain principles for better risk reporting.

The Securities Exchange Commission (SEC) of the United States of America (USA) also has a list of proxy-disclosure enhancements (SEC, 2009), which include risk- and risk-managementrelated requirements. Accounting and related services firm Deloitte compiled a list of questions 
from these requirements to assess risk and risk-management disclosure of top listed companies in the USA (Deloitte, 2011; Deloitte, 2010). These requirements focus heavily on disclosure relating to the governance of risk such as the board's responsibilities and board and managerial structures.

A study by Solomon, Solomon, Norton and Joseph (2000:452) proposing a conceptual framework for corporate risk disclosure identified elements that needed to be clarified in order to be able to improve reporting on risk and risk management.

Currently, risk and risk-management reporting in South Africa is driven mainly by the King Report on Governance for South Africa, 2009 (I0D, 2009), referred to as King III. In its introduction the chairman, Prof. Mervyn $\varepsilon$. King SC, reasons that the informed investor assesses, inter alia, the quality of the company's risk management in order to make an informed assessment of the company's economic value (IOD, 2009). The guidance provided by King III to South African companies regarding risk disclosure is vague by requiring disclosure of:

- any 'undue, unexpected or unusual risks' and the related material losses incurred (including the causes of the losses) for the period under review,

- risks that may threaten the company's long-term sustainability, and

- the board's views on the effectiveness of the company's risk-management processes.

Two additional leading international guidelines on risk management were consulted during the course of the study to assist in interpreting the terminology and reasoning contained in the riskdisclosure guidelines. The two guidelines are:

- The International Standard on 'Risk Management - Principles and Guidelines', referred to as ISO 31000 (ISO, 2009), and

- The Committee of Sponsoring Organisations of the Treadway Commission's 'Enterprise Risk Management - An Integrated Framework', referred to as COSO (COSO, 2004).

These guidelines focus on the risk-management process rather than disclosure thereof in the annual statements.

\section{PROBLEM STATEMENT AND RESEARCH OBJECTIVES}

Due to recent corporate failures and the events surrounding the global financial crisis, investors require better risk and risk-management disclosure. King III (IOD, 2009) recognises this requirement, but does not provide detailed guidance on disclosure. This has led to superficial risk disclosure by South African companies.

The purpose of this study is to investigate risk disclosure that does not form part of IFRSregulated disclosure as part of the annual financial statements. The focus therefore is primarily on disclosure in narrative format, which serves to inform the investor about the key risks that the company is facing, the mitigation thereof and the risk-management process. An example of regulated disclosure is where IFRS requires certain financial-risk disclosure which will be observed during analysis of the annual financial statements, but may not necessarily form part of the company's principal risk list and principal risk-management practices.

The objectives of this study are twofold. Firstly, a tool, the risk-disclosure index, will be developed from the existing international research conducted on investors and their 
preferences. This tool has been developed for the management of South African companies, in the absence of the regulation of risk disclosure in South Africa, to be able to improve risk disclosure in the annual integrated report. Secondly, this tool will be used to ascertain current risk- and risk-management-disclosure practices of top listed companies in South Africa as measured against the disclosure guidelines and regulations summarised in the disclosure index. This will indicate areas in which disclosure can be enhanced.

\section{THE RISK-DISCLOSURE INDEX}

\subsection{Structure of the risk-disclosure index}

According to Solomon et al. (2000), the visible channel for the company's risk management strategy comprises formal public disclosure to its stakeholders. In the disclosure phase there should be reporting about the company's risk-management strategy, its properties and accomplishment as well as some forward-looking discussion of the company as a going concern.

The various guidelines and requirements on risk and risk management discussed in the literature section were used to develop the risk-disclosure index that can be used by management as a tool in enhancing the disclosure of risk and risk management in the annual integrated report.

Risk overlaps with the business model of the company, the discussion of future plans and prospects, the discussion of past performance, as well as with financial reporting information (ICAEW, 2011). As such it is difficult not to repeat information if risk should be reported on in a separate report where everything the investor should know about risk is discussed in one place. According to the findings of the FRC (2011), investors want more meaningful disclosure on risk. This could be achieved by discussing the company's business model, strategy, key risks and mitigation within one cohesive report. In a study where the preferences of institutional investors were tested, however, it was found that they are neutral about a general statement on business risk (Solomon et al., 2000).

The current study found that risks were reported separately from the disclosure on risk management in 16 of the 29 companies' integrated reports. Disclosure on risk management mostly formed part of the larger Corporate Governance section of the integrated report. The list of principal or key risks and mitigation thereof, if not included along with the disclosure on risk management, generally was in a separate report, earlier on in the integrated report, among discussion of strategy or the report of the Chief Executive Officer (CE0). Two companies did not disclose risks, other than financial risks required by IFRS, in their respective integrated reports.

For the purposes of this study, the disclosure index was therefore classified into two categories:

- Disclosure regarding risk management and

- Disclosure regarding principal risks identified and the mitigation of these risks.

\subsection{Disclosure regarding risk management}

Risk management is defined as 'coordinated activities to direct and control an organization with regard to risk' by ISO 31000 (ISO, 2009). COSO (2004) defines risk management more extensively as 'a process, effected by an entity's board of directors, management and other personnel, applied in strategy setting and across the enterprise, designed to identify potential events that 
may affect the entity, and manage risk to be within its risk appetite, to provide reasonable assurance regarding the achievement of entity objectives.'

The risk-disclosure index for risk management, contained in TABLE 1, was developed and composed from the international discussions and investigations reported on in the literature study. A detailed discussion of the disclosure requirements follows after the table.

TABLE 1: Risk-disclosure index for risk management

\begin{tabular}{|c|c|c|}
\hline & Disclosure & Source \\
\hline RMl & Reference to King III. & JSE \\
\hline RM2 & Note that the full board is responsible for risk. & King III, SEC \\
\hline RM3 & $\begin{array}{l}\text { Note how the board is involved with regard to the company's risk appetite or } \\
\text { overall risk tolerance. }\end{array}$ & SEC, King III \\
\hline RM4 & $\begin{array}{l}\text { Note that the audit committee (or combined audit committee) is the } \\
\text { primary committee responsible for risk, or }\end{array}$ & SEC \\
\hline RM5 & Note that the company has a separate board risk committee. & FRC \\
\hline RM6 & Note that the company has a chief risk officer (CRO) or related position. & FRC \\
\hline RM7 & $\begin{array}{l}\text { Note whether the CEO is responsible for risk management or how the C\&O is } \\
\text { involved. }\end{array}$ & coso, SEC \\
\hline RM8 & $\begin{array}{l}\text { Note whether a companywide corporate culture of risk management is being } \\
\text { fostered. }\end{array}$ & $\mathrm{FRC}, \mathrm{COSO}$ \\
\hline RM9 & Note whether the company has a risk committee at the management level. & $\begin{array}{l}\text { ISO, COSO, } \\
\text { SEC }\end{array}$ \\
\hline RM10 & Disclose whether risk management is aligned with the company's strategy. & $\mathrm{FRC}, \mathrm{COSO}$ \\
\hline RM11 & $\begin{array}{l}\text { Disclose the monitoring and review system in place to ensure continued } \\
\text { comprehensiveness and relevance of the risk-management system. }\end{array}$ & IRM \\
\hline RM12 & $\begin{array}{l}\text { Disclose the board's views on the effectiveness of the company's risk- } \\
\text { management processes. }\end{array}$ & King III \\
\hline RM13 & Refer either to ISO 31000 or COSO if applicable. & \\
\hline
\end{tabular}

Source: Compiled by the authors from applicable guidelines and requirements. The source where the incentive for each disclosure item can be found is indicated in the last column.

King III (IOD, 2009), in accordance with its predecessor, King II (IOD, 2002), burdens the board of directors with the ultimate responsibility for risk management.

Although the board takes full responsibility for risk management, the board committee responsible for risk must ensure that the board receives good-quality guidance and information and improve the quality of oversight (FRC, 2011). In the discussions led by the FRC (2011), the committee structure differed between participating entities, and participants were of the opinion that it would not be apt to enforce a specific structure for risk committees outside the financial sector. Many participants were of the opinion that the company's product should be the determining factor in the choice of a committee structure. It was found that separate 
committees were more to be found among entities in sectors where they were exposed to substantial safety, regulatory or ecological risks, e.g. the extractive industries (FRC, 2011). The participants who preferred separate risk committees argued that audit committees already have a lot of responsibilities or that a different set of skills may be required. Opponents were of the opinion that with a separate committee the separation of duties with regard to risk and risk management might be unclear.

It is also essential that there is no ambiguity within the company about the duties of senior executives with respect to risk management (FRC, 2011). According to participants in the FRC discussions, financial companies normally had a designated Chief Risk Officer (CRO). However, this was not always the case in other companies, where the role of CRO was sometimes linked to the title of Chief Executive Officer ( $C E O)$ or Chief Finance Officer (CFO). Many participants felt that the $C \varepsilon 0$ should take final responsibility for risk; however, there was deviation in practice (FRC, 2011).

Risk management should be embedded in the corporate culture, with the board and management setting the example for the rest of the company (COSO, 2004; FRC, 2011). It is of the utmost importance that the chairman and $C \varepsilon 0$ are seen to live the principles that they promote (COSO, 2004). The FRC (2011) found that in practice this was done by the use of value statements, codes of conduct and by being clear about any risks or practices that will not be tolerated. In the discussions held by the FRC (2011), it was found that prominence was given to openness throughout the company, which enables management and personnel to report their concerns in a timely manner.

The participants at the FRC (2011) discussion were in general agreement that the routine oversight and management of individual risks were the responsibility of senior and line management, rather than the board. The board must assure itself that these duties were being performed efficiently. Transparency and clear lines of accountability throughout the company are imperative for effective risk management. Responsibility for managing specific risks must be assigned to staff members at all levels of the company.

According to Ballou and Heitger (2008), it is imperative for the long-term success of a company to link its risk-management processes to its strategic decision-making process. In his introduction to King III (IOD, 2009), Mervyn King, SC, says that 'strategy in itself involves risk because one is dealing with future events'.

In accordance with the definition of risk management it is clear that risk management should be a fundamental part of the company's strategic management (IRM, 2002). It should therefore be a constant, but continually improving process integral to the company's strategy and as such address all risks systematically (ISO, 2009).

Effective risk management involves a reporting and evaluation system to make sure that risks are effectively identified and evaluated and that suitable controls are in position (IRM, 2002). There should be regular monitoring of the risk-management system, which serves to ensure that there are sufficient controls in position and that the risk-management processes are understood and complied with. Accordingly, King III (IOD, 2009) requires the board to disclose its views on the effectiveness of the company's risk-management processes. ISO 31000 and COSO are leading international guidelines available to assist the board and management in developing and maintaining risk-management processes. 


\subsection{Disclosure regarding principal risks identified and the mitigation of these risks}

A definition of risk is the 'effect of uncertainty on objectives' (ISO, 2009) and is measured broadly as 'the combination of the probability of an event and its consequences' (IRM, 2002). Events have both an upside and a downside, and as such risk both has a positive as well as a negative side (ISO, 2009; COSO, 2004). In the context of risk reporting, it is mostly about risk in the negative sense (ICAEW, 2011).

The risk-disclosure index for risks and risk identification as contained in TABLE 2 was developed and composed from the international discussions and investigations reported on in the literature study. A detailed discussion of the disclosure requirements follows after the table.

TABLE 2: Risk-disclosure index for risks and risk identification

\begin{tabular}{|c|c|c|}
\hline & Disclosure & Source \\
\hline RII & $\begin{array}{l}\text { Disclose the main processes used by the risk-management systems to } \\
\text { identify risks. }\end{array}$ & IRM \\
\hline $\mathrm{RI} 2$ & Disclose principal risks, rather than listing all possible risks. & FRC, ICAEW \\
\hline RI3 & Disclose company-specific risks, rather than the reporting of general risks. & FRC \\
\hline RI4 & $\begin{array}{l}\text { Provide a discussion on each risk itself, rather than just cryptically listing the } \\
\text { risk. }\end{array}$ & FRC, ICAEW \\
\hline RI5 & Indicate the cause of each risk, even if just general. & ICAEW \\
\hline RI6 & $\begin{array}{l}\text { Note the possible impact that the possible occurrence of the risk event may } \\
\text { have on the company in general. }\end{array}$ & ICAEW \\
\hline RI7 & Support risk disclosure by quantitative disclosures. & ICAEW \\
\hline RI8 & $\begin{array}{l}\text { Note what impact the possible occurrence of the risks reported may have, } \\
\text { specifically on the achievement of the company's strategic objectives. }\end{array}$ & $\mathrm{FRC}$ \\
\hline RI9 & Disclose how principal risks reported are/were being mitigated. & FRC \\
\hline RIIO & $\begin{array}{l}\text { Disclose the company's risk appetite, even if only to state whether the risk } \\
\text { appetite is increasing or becoming more risk averse. }\end{array}$ & King III, FRC \\
\hline RIIl & $\begin{array}{l}\text { Explain changes in the company's risk exposure over the previous } 12 \text { months } \\
\text { as a result of changes to the strategy or business environment. }\end{array}$ & ICAEW, FRC \\
\hline RI12 & $\begin{array}{l}\text { Indicate if the company's risk exposure might change in the future, as a } \\
\text { result of changes to the strategy or business environment. }\end{array}$ & ICAEW \\
\hline
\end{tabular}

Source: Compiled by authors from applicable guidelines and requirements. The source where the incentive for each disclosure item can be found is indicated in the last column.

Investors should be able to understand the process whereby the company identifies the risks, and the reporting thereof. The purpose of risk identification is to 'identify an entity's exposure to uncertainty' (IRM, 2002) that may affect an 'entity's' ability to meet its strategic objectives (ISO, 2009; COSO, 2004). In order to be able to classify risk exposure, an exhaustive understanding of the company, the market in which it operates, the legal, social, political and 
cultural environment in which it functions, as well as its strategic and operational objectives is necessary. Risk identification should be done in a systematic way to make sure that all major events that may have an adverse effect on a company's ability to meet its objectives have been identified (ISO, 2009; COSO, 2004).

Investors who participated in the meetings of the FRC (2011) felt that risk disclosure could improve significantly. Some institutional investors said that their main source of assurance in assessing the quality of risk management was the quality of the board rather than official external reporting. The investors felt that long lists of risks were not very helpful, and that boards could rather concentrate on major strategic risks. They suggested improvements such as: linking risk disclosure to a discussion of the business model; a discussion on changes to the strategy; information on how the company might change in the future; and clarification on the consequences of these changes for the company's risk exposure.

According to the participants of the FRC discussions (2011), management needs to focus specifically on the risks that could result in strategic objectives not being achieved, those that can result in destabilising the long-term sustainability of the company, as well as those that result from external developments, such as regulatory and geopolitical change. The rapidity with which risks can affect the company, with a 'near-instantaneous global transmission of failure' emphasises the need for a solid crisis-management plan, which includes earlier agreement on the responsibilities of the chairman and CEO during such a crisis.

The participants from companies (FRC, 2011) were cautious not to reveal sensitive information. Too much disclosure on risks could result in the risk materialising. King III (IOD, 2009) does recognise that due regard should be given to a company's commercially privileged information when risk disclosure is considered.

Disclosing risk without providing adequate contextual information is deemed uninformative (ICAEW, 2011). The investors need to be informed what each risk means and how it might affect the company, as they do not possess the detailed knowledge on the business and its context to the same extent that management does.

The ICAEW (2011) suggests that referral in the descriptive risk information to other sections of the annual report, which contains valuable quantitative information on risk, as well as the provision of any additional quantitative analysis that may complement risk reporting, enhances the verifiability of risk reporting.

Suggestions for enhanced risk disclosure included disclosing how key risks are being mitigated (FRC, 2011). It was concluded that a focus on 'net risk' could be perilous. The board should have an understanding of the company's gross risk - that is, the company's exposure to risk and the combination of various risks, before the mitigation procedures are applied.

According to King III (IOD, 2009), where a company's risk appetite deviates materially from the company's overall risk-tolerance level, this should be disclosed in the integrated report. Participants from companies at the FRC (2011) meetings felt that defining and disclosing the company's risk appetite was problematic, as risk appetite adjusted along with market conditions, but some agreed that there is a need to convey more useful information in this regard.

The link between strategy and risk (FRC, 2011) is again emphasised by the requirement that current and expected changes to the company's risk exposure due to current and expected 
changes to the strategy or business environment be reported (ICAEW, 2011). This enhances the forward-looking value of risk disclosure.

\section{METHODOLOGY TO INFER CURRENT RISK DISCLOSURE PRACTICES}

The risk- and risk-management disclosure practices of the Top 40 companies listed on the JSE, excluding companies listed in the financial sector, were analysed, using the risk-disclosure index that was compiled as discussed in the previous section.

As compliance with King III became one of the listing requirements of the JSE, it became compulsory for all companies listed on the JSE to produce an integrated report for all financial years ending on or after 1 March 2011, or to explain why they were not doing so (JSE, 2012). This is significant, as King III requires risk- and risk-management-related disclosure in the integrated report (IOD, 2009).

This study focuses specifically on the Top 40 listed companies. Previous studies also took this approach to analyse Top 40 listed companies (Barac \& Moloi, 2010; Marx \& Voogt, 2010). The Top 40 index of companies listed on the JSE as on 1 March 2011 was used to select the companies that were studied.

According to Ballou and Heitger (2008:38), financial services companies are more likely to measure risks quantitatively, while entities that focus more on operational risks, often use more qualitative measurements. The disclosure of risk and risk management can be expected to differ depending on whether a company is in a more regulated industry, like the financial companies. Financial companies were therefore excluded from this study, as they are risk-management entities, which can be expected to report on risk by a different set of standards (Linsley \& Shrives, 2006:392). From the 29 non-financial companies examined, 15 could be classified broadly as industrial companies and 14 as mining companies.

The integrated reports of the selected companies for their financial years ending on or between 31 March 2011 and 29 February 2012 were obtained in electronic format directly from their respective websites.

As this study investigates the current state of disclosure of risk and risk-management information, it is important to note that only disclosed information is reported on. It may very well be that some of the companies that didn't disclose certain structures or processes may actually have them in place, but failed to report this in their integrated reports.

Each integrated report was analysed by two of the authors to ensure completeness and accuracy. To ensure consistency, one specific author was party to the analysis of all 29 integrated reports.

As there is, except for King III, no compulsory risk disclosure for non-financial companies in South Africa, the expectation is that there will not be uniformity in the disclosure on risk and risk management. For the purposes of this study, uniformity is defined as a statistically significant number of the 29 companies that report on the specifics of the requirement analysed. For each requirement listed in TABLE 1 and 2 the following hypothesis will be tested:

$\mathrm{H}_{1}$ : There is a statistically significant number of the companies examined that report on the specific aspect in the integrated report. 
Statistical significance will be tested by means of the binomial probability distribution which is typically used in determining significance in discrete data. The binomial probability distribution indicates the probability that a success will occur $x$ times in $n$ trials. In this study a success is represented by the disclosure of a specific requirement in the integrated report and $n$ equals 29 companies investigated. If evidence does not support $\mathrm{H}_{1}$ for a specific disclosure requirement, $\mathrm{H}_{1}$ will be rejected in favour of $\mathrm{H}_{0}$, which will result in the inference that there is not enough evidence that uniformity in risk disclosure exists among the companies studied.

\section{RESULTS}

The disclosure requirements as set out previously in the risk-disclosure index were surveyed in practice for the non-financial Top 40 companies, and the results are summarised in FIGURES 1 and 2. The number of companies that did disclose the specific requirement $i$ is reported in the bar for each requirement in each figure.

According to the theory of the binomial probability distribution it was determined that, when 19 companies $(x)$ disclose the requirement it was statistically significant at the $95 \%$ confidence interval. When 21 companies disclose the requirement, this number increases to being highly statistically significant at a $99 \%$ confidence interval. The bar graphs that end to the right of the dotted line of FIGURES 1 and 2 are the requirements where a significant majority of companies, at a $95 \%$ confidence level, did disclose the specifics as required.

\subsection{Results for risk management disclosure}

The results for the disclosure on risk management are summarised in FIGURE 1.

The disclosure requirements where a materially significant majority of the 29 companies did comply with, and $\mathrm{H}_{1}$ cannot be rejected at a $95 \%$ confidence level (evidence support $\mathrm{H}_{1}$ ), are RMI, RM2, RM4, RM8, RM10, RM11 and RM12. This implies that, currently, uniform practices do exist with regard to disclosure of these requirements by the top listed companies in South Africa. With the exception of RM4, all of these also indicate that a significant majority, at a $99 \%$ confidence level, do disclose the respective requirements.

Only five companies did not refer to King III (RMI), and they all are dual-listed companies, with four of them referring to the UK Corporate Governance code, and the other one referring to the Swiss code for best practice for corporate governance.

The disclosure of RM2 was also required by King II, and it is therefore not surprising that a materially significant majority of the 29 companies mentioned that risk is the responsibility of the full board of directors. This responsibility is transferred to either the audit committee or a specific risk committee. In a significant majority of the cases, the audit committee is still primarily responsible for risk and risk management (RM4). In all the instances where the audit committee is not primarily responsible, a separate risk committee takes the responsibility (RM5). It is interesting to note that of the 14 companies categorised as mining companies, only $28.6 \%$ (four) had a separate risk committee on board level, as opposed to a $40 \%$ (six out of 15 ) prevalence level among the rest of the companies. This is the direct inverse of the findings at the FRC discussions as referred to in the section on the risk-disclosure index. 


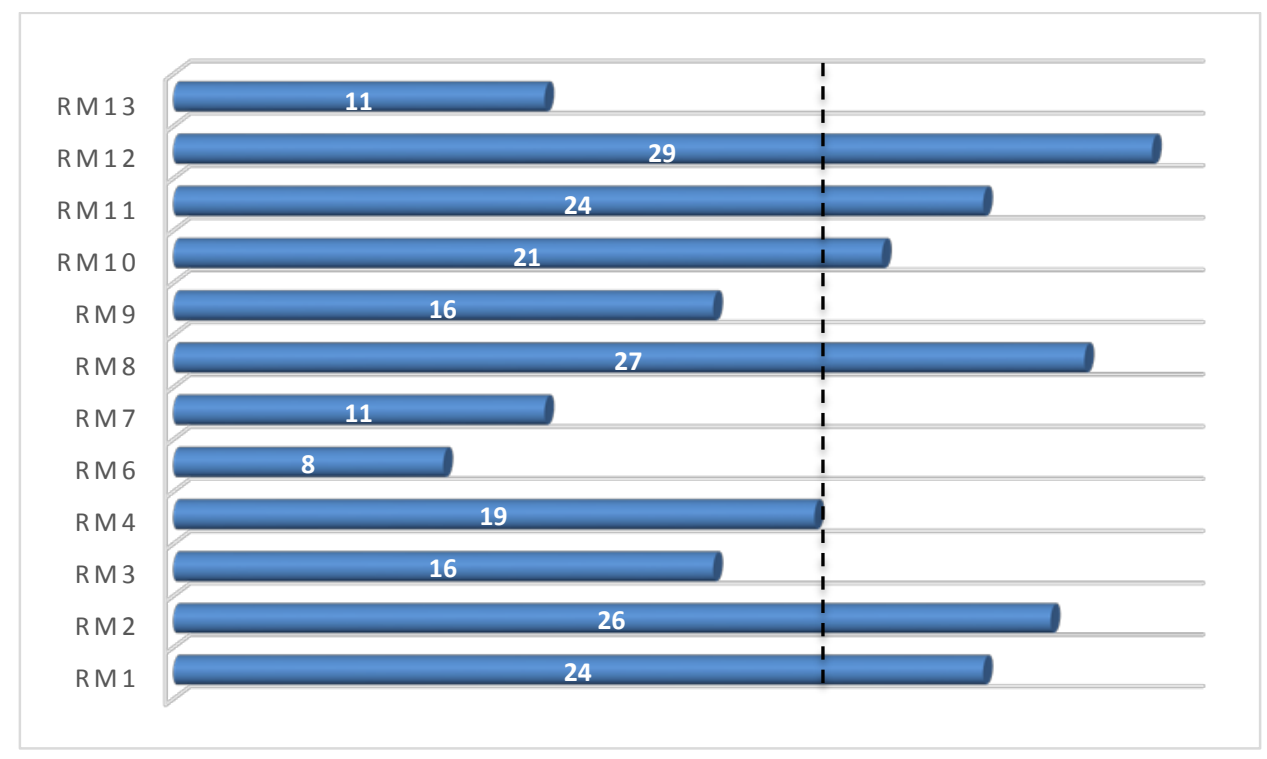

FIGURE 1: Current practices in disclosure on risk management

\section{Source: Compiled by authors from research results}

Note: RM refers to each correspondingly numbered disclosure requirement in TABLE 1 . Bars that end to the right of the vertical dotted line indicate requirements for which a statistically significant majority do disclose at a $95 \%$ confidence level.

Current practice by top listed companies in South Africa seems to acknowledge the fact that in order to be successful in risk management, there needs to be a corporate-wide culture of understanding, identification and management of risks associated with the company and its environment (RM8). A significant majority of the 29 non-financial companies examined are also aware of the fact that risk management needs to be linked to companies' strategies, as they disclosed that risk-management processes were aligned with their strategies (RM10).

Although the monitoring and review system in place to ensure continued comprehensiveness and relevance of the risk-management system was also disclosed in the significant majority of cases (RM11), the disclosure on this system was not necessarily in detail.

All of the companies examined did disclose the boards' views on the effectiveness of the companies' risk-management processes (RM12), although the format of disclosure varied. Some companies included a specific statement by the board on its view of the effectiveness of the processes, while others stated that the board is satisfied that the board committee that is responsible for risk management fully fulfilled its duties, implying that this includes effective risk management. This inconsistency represents an area for enhancement, as it is a specific riskdisclosure requirement of King III (IOD, 2009).

For the other requirements, RM3, RM6, RM7, RM9 and RM12, there was not a statistically significant majority that disclosed the information. In these cases, $H_{1}$ is therefore rejected.

RM6, which requires disclosure on the fact that there is a separate CRO if this is indeed the case, was rarely disclosed. The fact that companies did not disclose anything can be as a result of 
them not having appointed a separate CRO and that this function is still absorbed by the CEO or CFO.

Although it is the responsibility of the board to ascertain the risk-tolerance levels of the company according to King III (IOD, 2009), there are not a materially significant number of companies that do mention this part of their functionality (RM3). Few companies disclose more detail about the process or calculation of risk-tolerance levels, rather than just mentioning the fact that it is part of the board's responsibilities.

The CEO's role in risk management was not defined comprehensively. In some cases there was a cryptic reference to the CEO's involvement in the risk-management process (RM7). This is an area that needs improvement, as $\operatorname{COSO}$ and the FRC discussions place such an emphasis on the CEO's role. This situation is exacerbated by the fact that a majority of the companies do not report on having an appointed CRO.

Risk-management processes and systems differ among companies in different industries, and accordingly uniformity in the disclosure about the structure of risk management in the entities should not be expected. The structure for risk management varies among the 29 companies examined, as only 16 reported that they have a risk committee at management level (RM9).

It is interesting to note that only 11 of the 29 companies (38\%) referred to ISO 31000 or COSO in relation to their respective risk-management processes (RM13). The investor can consequently not ascertain which standards are used in the development and maintenance of the overall riskmanagement processes.

\subsection{Results for risk identification and mitigation disclosure}

The results for the disclosure of risk identification and mitigation are summarised in FIGURE 2.

The requirements where a materially significant majority of the companies did comply, and where $H_{1}$ cannot be rejected at a $95 \%$ confidence level (evidence support $H_{1}$ ), are RI2, RI4, RI5 and RI9. This entails fewer requirements for which uniform current practice of disclosure of the requirement can be inferred than is the case with regard to risk-management disclosure. The explanation for this phenomenon is that more of the requirements for risk-management disclosure are regulated, while the disclosure of risk identification and mitigation is largely voluntarily.

The number of risks identified and reported in the integrated report by the 29 companies varies from 0 to 47, with an average of 13 risks reported. A positive finding is the fact that in a statistically significant number of cases it was only principal risks that have been reported (RI2 - significant at a $99 \%$ confidence level).

Although a materially significant number of companies described each risk, 10 companies still reported very cryptically on the risk, leaving much to the imagination of the investor (RI4). This applies almost equally to the cause of the risk (RI5 - significant at a $98 \%$ confidence level). In some instances the cause is discussed in very general terms such as a statement linking it to the business model of the company without elaboration on the true source of the risk. This lack of contextualisation (RI4 and RI5) present at some of the Top 40 companies indicates uninformative risk disclosure, according to the views of the ICAEW (2011). 


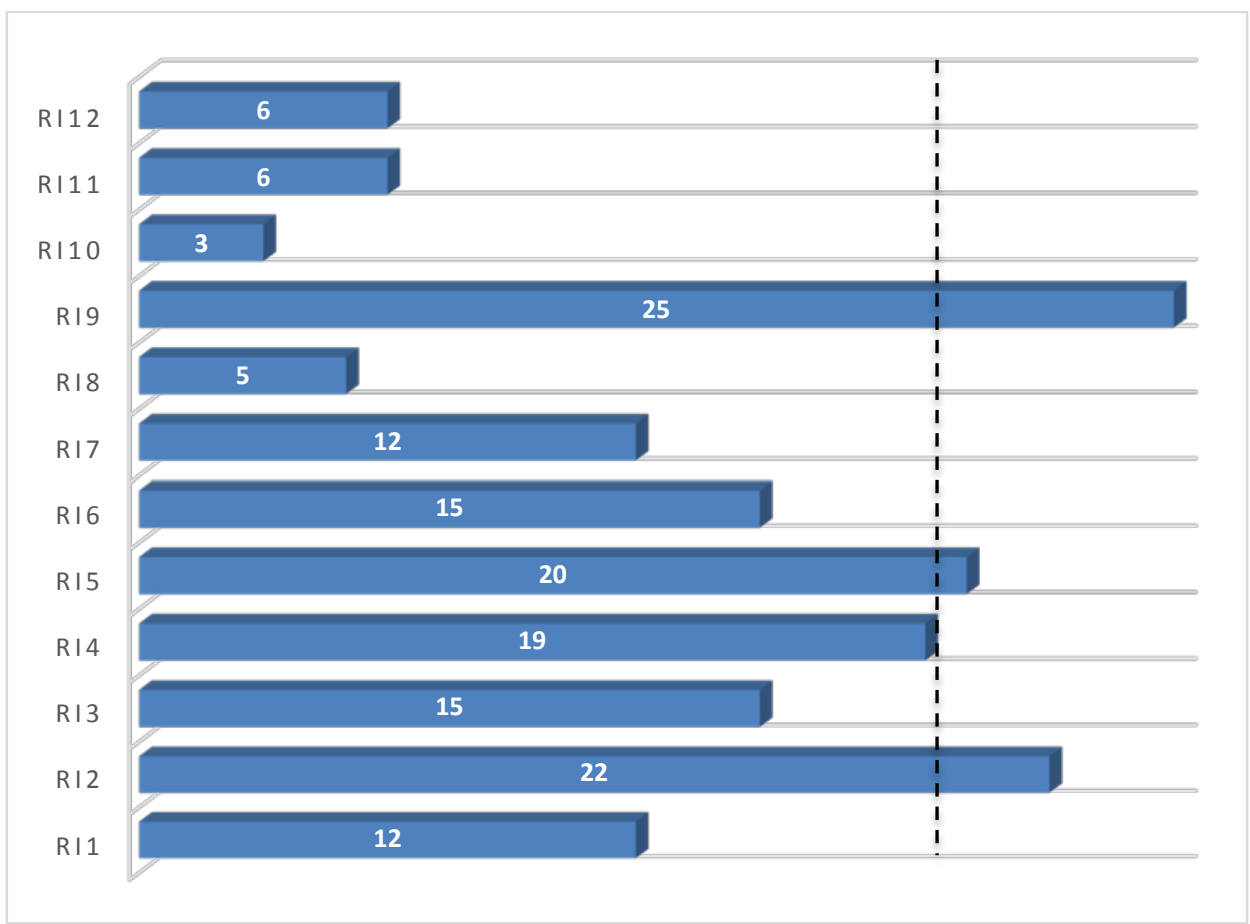

\section{FIGURE 2: Current practices in disclosure in risk identification and mitigation}

Source: Compiled by authors from research results

Note: RI refers to each correspondingly numbered disclosure requirement in TABLE 2. Bars that end to the right of the vertical dotted line indicate requirements for which a statistically significant majority do disclose at a $95 \%$ confidence level.

The significant majority of the 29 companies do report on the mitigation of the risks identified (RI9 - significant at a $99 \%$ confidence level). This disclosure is however still hampered by the fact that risks are not quantitatively substantiated, and therefore the investor will not be able to satisfactorily evaluate whether the mitigation steps in place will be adequate.

For the other requirements (i.e. except for RI2, RI4, RI5 and RI9), there were not a materially significant majority that disclosed information, and $H_{1}$ is therefore rejected. Uniformity cannot be inferred regarding disclosure of these requirements as current practices being followed by the top listed companies in South Africa.

Out of the 29 companies examined, only 12 companies did report on the risk-management system that is used to identify risks (RII). This results in the investor not being able to evaluate whether the system is sufficient to identify all major risks for 17 of the companies.

The format of the disclosure of the principal risks that the companies face is not uniform, as some companies reported risks that are specific to each respective company's circumstances, while other companies report on general risks facing most South African companies (RI3). Investors essentially require a more specific discussion of risks facing a company in order to ascertain the unsystematic risk of that company. 
Although some companies do mention the impact that the risks may have on the business of the company (RI6), it tends to be a general statement, with little discussion and objective substantiation (RI7). Among the companies that did provide some quantitative disclosure, it was often related to a single risk. A select few of the companies did, in accordance with the recommendations of the ICAEW (2011), refer to other sections of the integrated report that contain quantitative information on particular risks.

The disclosure requirements in relation to which very few of the 29 companies did report are RI8, $\mathrm{RI} 10, \mathrm{RIIl}$ and RI12. The relevant requirements are mostly linked to strategy, risk appetite or more of a forward-looking nature.

Many of the companies do not link the risks with the strategic objectives and the impact thereon (RI8). This is in stark contrast to the statements made by a significant majority of the companies that risk management is aligned to the specific company's strategy (RM10) and requires significant improvement.

Risk appetite was not quantified by 26 companies, and among the three companies that did disclose information on risk appetite to some degree the disclosure was something general as in 'our risk appetite did not change' (RI10).

Forward-looking risk disclosure is still lacking, as only a few companies disclosed changes in their risk exposure over the past 12 months (RII1), or changes expected in future (RI12). Disclosure that was noted was very cryptic.

\section{CONCLUSION}

This study serves to provide management of South African companies with a tool which indicates current requirements according to international and local guidelines on risk and riskmanagement disclosure. The tool is in the form of a risk-disclosure index that is divided into two categories, namely:

- Disclosure regarding risk management, encompassing 13 requirements; and

- Disclosure regarding principal risks identified and the mitigation of these risks, encompassing 12 requirements.

This index was then used to identify the current practices related to risk and risk management applied by top listed companies in South Africa. This was done by ascertaining whether or not any uniformity exists in the risk-disclosure practices of the 29 non-financial companies within the Top 40 index of the JSE Securities Exchange with regard to annual integrated reports for financial years ending on or between 31 March 2011 and 29 February 2012.

In the case of risk-management disclosure uniform current practices regarding disclosure of a requirement (as determined by means of the binomial distribution) could be inferred for $58.3 \%$ of the requirements. The applicable requirements are:

- Refer to King III;

- Note that the full board is responsible for risk;

- Note as applicable: 
0 that the audit committee (or combined audit committee) is the primary committee responsible for risk; or

O that the company has a separate board risk committee;

- Note whether a companywide corporate culture of risk management is being fostered;

- Disclose whether risk management is aligned with the company's strategy;

- Disclose the monitoring and review system in place to ensure continued comprehensiveness and relevance of the company's risk management systems; and

- Disclose the board's views on the effectiveness of the company's risk-management processes.

For disclosure on risk identification and mitigation current practices regarding disclosure of a requirement could be inferred for only $33.3 \%$ of the requirements. The applicable requirements are:

- Disclose principal risks, rather than listing all possible risks;

- Provide a discussion on each risk, rather than just cryptically listing the risk;

- Indicate the cause of each risk; and

- Disclose how principal risks are being mitigated.

Current practices by the top listed companies in South Africa regarding meaningful disclosure in the areas of risk management and risk identification and risk mitigation run the risk of appearing superficial due to the lack of meaningful forward-looking disclosure and the failure to link the possible impact of risks to the strategic objectives that could be affected.

Limited and general discussions and a general lack of quantitative disclosure still limit the informative value of the disclosure of risks identified and the mitigation of these risks from the investors' point of view.

It is recommended that the boards of publicly traded companies in South Africa utilise the disclosure index to benchmark the risk-disclosure practices of each respective company which they govern in order to enhance the company's risk-management and disclosure systems. This will enable investors to make informed decisions pertaining to a company's risk profile and should in the long run provide the company with the benefit of a decrease in the cost of capital.

\section{LIST OF REFERENCES}

Abdo, A. \& Fisher, G. (2007). The impact of reported corporate governance disclosure on the financial performance of companies listed on the JSE. Investment Analysts Journal, 66, pp. 43-56.

Abraham, S. \& Cox, P. (2007). Analysing the determinants of narrative risk information in UK FTSE 100 annual reports. The British Accounting Review, 39, pp. 227-248.

Abrahamson, $\varepsilon$. \& Amir, $\varepsilon$. (1996). The information content of the president's letter to shareholders. Journal of Business Finance \& Accounting, 23(8), pp. 1157-1182.

Amran, A., Bin, A.M.R. \& Hassan, B.C.H.M. (2008). Risk reporting: An exploratory study on risk management disclosure in Malaysian annual reports. Managerial Auditing Journal, 24(1), pp. 39-57. 
Ballou, B. \& Heitger, D.L. (2008). Integrating governance risk and reporting to create long-term value. Strategic Finance, May, 36, pp. 41.

Barac, K. \& Moloi, T. (2010). Assessment of corporate governance reporting in the annual reports of South African listed companies. Southern African Journal of Accountability and Auditing Research, 10, pp. 19-31.

Beretta, S. \& Bozzolan, S. (2004). A framework for the analysis of firm risk communication. The International Journal of Accounting, 39, pp. 265-288.

Berk, A.S. \& Loncarski, I. (2011). Are exogenous requirements sufficient to induce corporate risk management activities? Post-Communist Economies, 23(01), pp. 119-137.

Coetzee, G.P. \& Lubbe, D. (2013). The risk maturity of South African private and public sector organisations. Southern African Journal of Accountability and Auditing Research, 14, pp. 45-56.

Committee of Sponsoring Organizations of the Treadway Commission. (2004). Enterprise Risk Management - Integrated Framework. United States of America: COSO.

Deloitte. (2010). Risk Intelligent Proxy Disclosures: Transparency into board-level risk oversight. United States of America: Deloitte Development LLC.

Deloitte. (2011). Risk Intelligent Proxy Disclosures - 2011: Have risk-oversight practices improved? United States of America: Deloitte Development LLC.

Deloitte. (2012). Integrated Reporting: Navigating your way to a truly Integrated Report. Johannesburg: Deloitte.

Dobler, M. (2008). Incentives for risk reporting - A discretionary disclosure and cheap talk approach. The International Journal of Accounting, 43, pp. 184-206.

Financial Reporting Council (FRC). (2011). Boards and Risk - A Summary of Discussions with Companies, Investors and Advisers, London: FRC.

Havenga, A. \& Venter, P. (2007). The perceived value of Enterprise Risk Management in the South African business environment. Southern African Business Review, 11 (3), pp. 74-94.

Holt, G.A. (2006). Chapter 27 - The evolution of risk reporting. Risk management: A modern perspective. Boston: Academic Press.

Institute of Chartered Accountants for England and Wales (ICAEW). (2011). Reporting Business Risks: Meeting Expectations. London: ICAEW.

Institute of Directors (IOD). (2002). King // Report on Corporate Governance for South Africa. Johannesburg: IOD.

Institute of Directors in South Africa (IOD). (2009). The King III Report and Code on Corporate Governance for South Africa. Johannesburg: IOD.

Institute of Risk Management (IRM). (2002). A Risk Management Standard. London: AIRMIC, ALARM, IRM.

International Accounting Standards Board (IASB). (2010). IFRS Practice Statement. Management Commentary: A Framework for Presentation. London: IFRS Foundation.

International Organization for Standardization (ISO). (2009). International Standard ISO 31000: Risk Management-Principles and Guidelines. Switzerland: ISO. 
Janse van Vuuren, H. (2006). Disclosing Risk Management Policies in Financial Statements. Unpublished masters' dissertation. Potchefstroom: North-West University.

Jorgensen, B.N. \& Kirschenheiter, M.T. (2003). Discretionary risk disclosures. The Accounting Review, 78(2), pp. 449-469.

JSE Listing requirements, Service Issue 14.pdf. (2012). Available: http://www.jse.co.za/How-ToList/Listing-requirements/JSE-listing-requirements.aspx. (Accessed 7 June 2012).

Lajili, K. \& Zéghal, D. (2005). A content analysis of risk management disclosures in Canadian annual reports. Canadian Journal of Administrative Sciences, 22(2), pp. 125-142.

Linsley, P.M. \& Shrives, P.J. (2005). Examining risk reporting in UK public companies. The Journal of Risk Finance, 6(4), pp. 292-305.

Linsley, P.M. \& Shrives, P.J. (2006). Risk reporting: A study of risk disclosures in the annual reports of UK companies. The British Accounting Review, 38, pp. 387-404.

Marx, B. \& Voogt, T. (2010). Audit committee responsibilities vis-á-vis internal audit: how well do Top 40 FTSE/JSE listed companies shape up? Meditari Accountancy Research, 18(1), pp. 17-32.

Merkl-Davies, D.M. \& Brennan, N.M. (2007). Discretionary Disclosure Strategies in Corporate Narratives: Incremental Information or Impression Management? Journal of Accounting Literature, 26, pp. 116-194.

Miihkinen, A. (2012). What drives quality of firm disclosure? The impact of a national disclosure standard and reporting incentives under IFRS. The International Journal of Accounting, 47, pp. 437468.

Ntim, C.G., Opong, K.K., Danbolt, J. \& Thomas, D.A. (2012), Voluntary corporate governance disclosures by post - Apartheid South African corporations. Journal of Applied Accounting Research, 13(2), pp. 122-144.

Oliveira, J., Rodrigues, L.L. \& Craig, R. (2011). Risk-related disclosures by non-finance companies: Portuguese practices and disclosure characteristics. Managerial Auditing Journal, 26(9), pp. 817839.

Rajab, B. \& Handley-Schachler, M. (2009). Corporate risk disclosure by UK firms: Trends and determinants. World review of Entrepreneurship Management and Sustainable Development, 5(3), pp. 224-243.

Securities Exchange Commission of the United States of America (SEC). (2009). 17 CFR Parts 229, 239, 240, 249 and 274, Proxy Disclosure Enhancements. New York: SEC.

Solomon, J.F., Solomon, A., Norton, S.D. \& Joseph, N.L. (2000). A conceptual framework for corporate risk disclosure emerging form the agenda for corporate governance reform. The British Accounting Review, 32, pp. 447-478.

Vorster, Q. \& Lubbe, D.S. (2000). Empiriese bevindings aangaande die nakoming van korporatiewe beheerriglyne in jaarverslae van sekere genoteerde Suid-Afrikaanse maatskappye. Meditary Accountancy Research, 8, pp. 99-214. 
Enslin, Bruwer \& Viljoen 